\title{
First Pollen Record in South America. Commentary: Die Zeichenschrift der Pollenstatistik
}

\author{
Vera Markgraf ${ }^{1,2 *}$ \\ ${ }^{1}$ Institute of Arctic and Alpine Research, University of Colorado, Boulder, CO, USA, ${ }^{2}$ School of Earth Sciences and \\ Environmental Sustainability, Northern Arizona University, Flagstaff, AZ, USA
}

Keywords: South America, Tierra del Fuego, pollen records, von Post, history of palynology

\section{A commentary on}

Die Zeichenschrift der Pollenstatistik

by Von Post, L. (1929). Geol. Fören. För. 51, 543-565. doi: 10.1080/11035892909449566

By the end of the 1920's, pollen analysis had become an actively growing field of research with scientists throughout Northern and Central Europe producing pollen diagrams. Erdtman (1924) even had ventured farther afield studying peats from southern New Zealand. At this point, Von Post (1929) apparently felt the need to re-iterate some of the basic principles of pollen analysis, a technique he had introduced in 1916, including questions of which taxa should be represented in the pollen sum, use of absolute versus percentage data and type of symbols to graphically depict the different pollen taxa. Among the examples of diagrams Von Post (1929) presented in this publication were pollen diagrams from two $150 \mathrm{~cm}$ long cores from a bog at the eastern end of Lago Fagnano in Tierra del Fuego, Argentina, a site that has since become submerged following an earthquake in the 1940's. A characteristic volcanic ash layer allowed correlation between the two cores, one from the center of the bog, the other from the margin. The material was given to von Post by C. Caldenius, who between 1925 and 1928 had mapped and analyzed glacial deposits on the Argentine side of the Andes from 42 to $53^{\circ} \mathrm{S}$ (Caldenius, 1932). Von Post (1929) analyses of the pollen assemblages of those two cores represent the very first vegetation history record from South America (see Markgraf, 1993). As such it pointed to the global applicability of the technique, which certainly was one of von Post's reasons for including the Tierra del Fuego records in this study (Von Post, 1929, p. 561). Given the focus of the paper, Von Post's (1929) other reason to present the pollen data was to discuss questions about pollen sum and pollen symbols to be used in diagrams from very different environments. The pollen types reproduced in the diagrams by 6 and 7 levels, respectively, are Nothofagus, Ericaceae, Gramineae and Cyperaceae (Figure 1), mentioning also the presence of several other herbaceous and tree pollen types. In contrast to the European pollen records available in the 1920s, primarily showing successions of diverse tree pollen types, the Tierra del Fuego pollen assemblages were dominated by only one tree pollen type, Nothofagus, abundant in the upper levels while non-arboreal taxa dominated the lower levels. Hence von Post concluded that non-arboreal taxa had to be included in the pollen sum, at that time generally assumed to represent strictly local, site-related conditions, irrelevant in discussions on regional vegetation histories. Differences in the pollen numbers between the central and the marginal peat core indicated to him, however, that Ericaceae had to represent a local signal. Despite of this, he decided to include Ericaceae in the diagram-after applying the adequate pollen sum calculation (p. 560: "sobald man die richtige Berechnungsweise gefunden hat!"). The Ericaceae percentages thus were calculated out-of-sum which was based on Nothofagus, Gramineae and Cyperaceae (Figure 1).

Interpreting the shift in pollen assemblages, from steppe taxa to forest, Von Post (1929) concluded that it represented a change from warmer and drier to cooler and wetter climates. Pollen morphological differentiation based on pore number of the three Nothofagus species, presently 


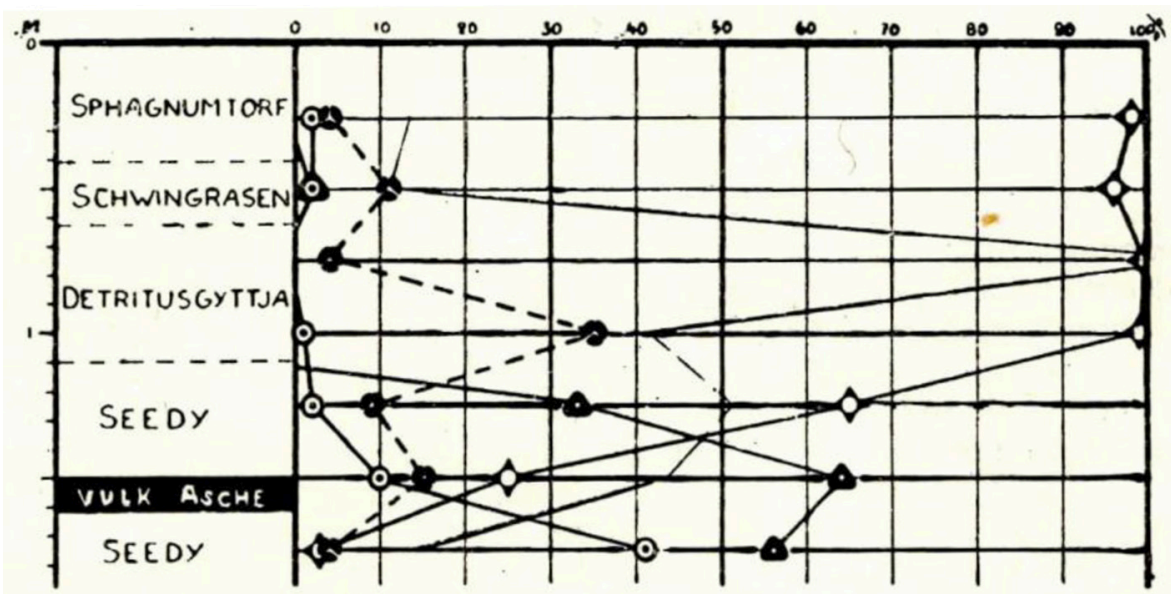

MoOr am ostlichen Ende des lago fagnano

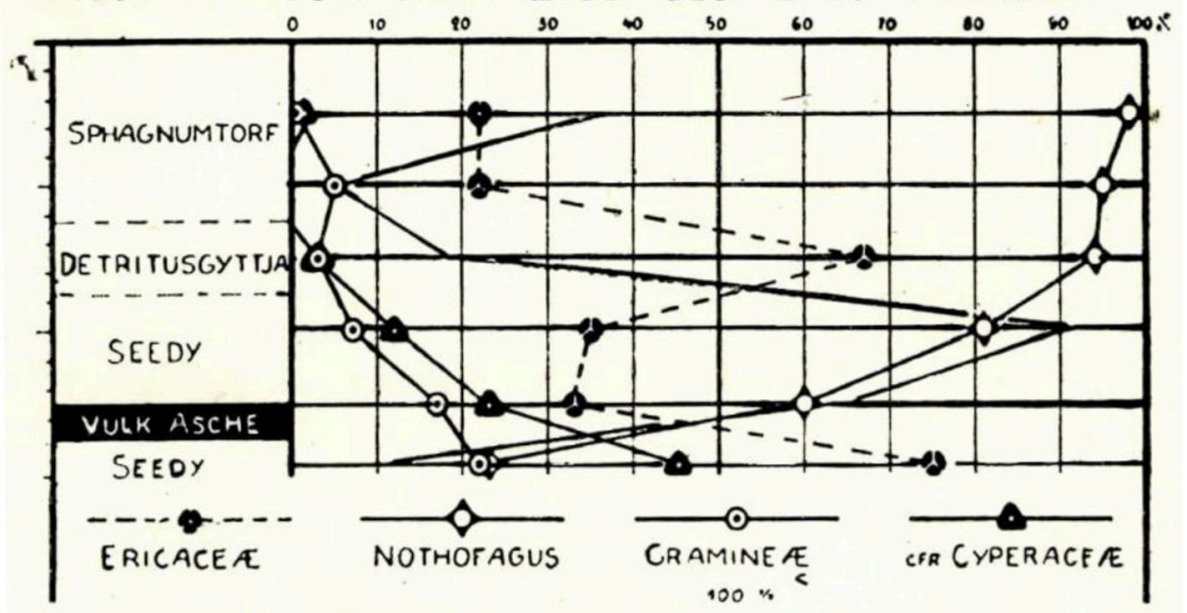

FIGURE 1 | Two diagrams from a bog at the eastern end of Lago Fagnano, Tierra del Fuego, Argentina (Von Post, 1929, p. 559; reproduced by Auer, 1949, p. 177). The same diagram was replotted, excluding Cyperaceae from the pollen sum and published by Markgraf (1983).

growing in the region, allowed further detail in interpreting the vegetation succession, related to changes in climate.

At the same time, between 1928 and 1929, the Geographical Society of Finland supported a scientific expedition to Tierra del Fuego. One of the scientists, Auer (1933), followed in von Post's footsteps analyzing the pollen content of peat cores from 33 sites, ranging from the western rainforest region to the eastern steppe. Presence of three characteristic volcanic ashes in the cores, analyzed geochemically by Salmi (1941), allowed correlations between the records that led Auer (1948, 1949) to propose tephrochronology as a new dating technique for postglacial sediments. Several of these records show treeless conditions followed by forest expansion at the base near the oldest of the three volcanic ashes. The shift from steppe to forest in Von Post's (1929) analyses near the youngest of the ash layers has also been found in several other cores (Auer, 1933).

This initial shift from treeless to forest conditions in Tierra del Fuego, just above the oldest volcanic ash layer, was assumed coeval with the postglacial expansion of forest in Northern Europe, on the basis of (1) today's climate conditions in both regions was considered comparable and (2) the similarity of climatic trends as interpreted from the pollen assemblage successions (Auer, 1933, 1949). Using the Blytt-Sernander (Blytt, 1876; Sernander, 1908) Scandinavian climate succession model and its nomenclature, dated by the Baltic Sea varve chronology (De Geer, 1912; Sauramo, 1929), this initial postglacial vegetation change in the Tierra del Fuego records was dated to the beginning of the Boreal period, i.e. about 7000 years BC (ca 9000 C 14 years BP) (Auer, 1949, p. 136). Despite these somewhat questionable assumptions, the shift from treeless conditions to Nothofagus forest was subsequently radiocarbon dated on material from one of the original cores analyzed by Auer (1933) (Bahia Beaubasin, Isla Clarence, site 23, diagram 41, Auer, 1933) and actually gave the age of $8820 \pm 290$ C14 years BP (Jungner, 1979; Markgraf, 1983).

Since those early explorations, South America in general and the southern portion of South America specifically have 
produced a wealth of paleoecological data (reviews e.g., Markgraf, 1993; Markgraf and Huber, 2010).

It was the pioneering research of these earlier scientists, many of them from Scandinavian countries, that subsequent research could build upon. Improved coring technology resulted in the recovery of materials going back to the times when fullglacial age ice had begun to recede from the Andean forelands. Radiocarbon dating, higher analytical resolution, multi-proxy analysis of the records and simplification of the diagrams, and no longer using the confusing symbols proposed by Von Post $(1916,1929)$ represented advances in reconstructing past environmental history of southern South America. Advanced

\section{REFERENCES}

Auer, V. (1933). Verschiebungen der Wald- und Steppengebiete Feuerland's in postglazialer Zeit. Acta Geogr. 5, 1-313.

Auer, V. (1948). Las capas volcánicas como nuevo método de cronología postglacial en Fuegopatagonia. Gaea VIII, 311-336.

Auer, V. (1949). Las capas volcánicas como base de la cronología postglacial en Fuegopatagonia. Rev. Invest. Agricol. Buenos Aires III, 49-208.

Blytt, A. (1876). Essay on Immigration of the Norwegian Flora during Alternating Rainy and Dry Periods. Christiana; Oslo: Alb. Cammermeyer.

Caldenius, C. (1932). Las glaciaciones cuaternarias de la Patagonia y Tierra del Fuego. Geogr. Ann. 14, 1-164. doi: 10.2307/519583

De Geer, H. (1912). Geochronologie der letzten 12000 Jahre. Geol. Rundsch. 3, $457-471$.

Erdtman, G. (1924). Studies in micropalaeontology IV: peat from Chatham Islands and Otago District. Geol. Fören. För. 46, 679-681.

Jungner, H. (1979). Radiocarbon Dates I. Radiocarbon Dating Laboratory, University of Helsinki, Report no. 1:77.

Markgraf, V. (1983). Late and postglacial vegetational and paleoclimatic changes in subantarctic, temperate, and arid environments in Argentina. Palynology 7, 43-70. doi: 10.1080/01916122.1983.9989252

Markgraf, V. (1993). Paleoenvironments and paleoclimates in Tierra del Fuego and southernmost Patagonia, South America. Palaeogeogr. Palaeoclimatol. Palaeoecol. 102, 53-68. doi: 10.1016/0031-0182(93)90005-4

Markgraf, V. (2001). Interhemispheric Climate Change. San Diego, CA: Academic Press. radiocarbon dating combined with other dating techniques (i.e. thermos-luminescens, paleomagnetic) made correlations realistic, including intra-hemispheric correlations (Markgraf, 2001). Given the restrictions of the early studies, including difficulty in traveling in these remote regions, it is truly amazing how much was accomplished and how many far-reaching ideas had been proposed, that subsequent research could only confirm.

\section{AUTHOR CONTRIBUTIONS}

The author confirms being the sole contributor of this work and approved it for publication.

Markgraf, V., and Huber, U. (2010). Late and postglacial vegetation and fire history in Southern Patagonia and Tierra del Fuego. Palaeogeogr. Palaeoclimatol. Palaeoecol. 297, 351-366. doi: 10.1016/j.palaeo.2010. 08.013

Salmi, M. (1941). Die postglazialen Eruptionsschichten Patagoniens und Feuerlands. Ann. Acad. Sci. Fenn. A III 2, 1-115.

Sauramo, M. (1929). The Quaternary Geology of Finland. Helsinki: Helsingfors Publisher.

Sernander, R. (1908). On the evidence of postglacial changes of climate furnished by the peat-mosses of northern Europe. Geol. Fören. För. 30, 456-478. doi: 10. 1080/11035890809445601

Von Post, L. (1916). Om skogsträdpollen I sydsvenska torfmosselagerföljder. Geol. Fören. För. 38, 384-390.

Von Post, L. (1929). Die Zeichenschrift der Pollenstatistik. Geol. Fören. För. 51, 543-565. doi: 10.1080/11035892909449566

Conflict of Interest Statement: The author declares that the research was conducted in the absence of any commercial or financial relationships that could be construed as a potential conflict of interest.

Copyright (C) 2016 Markgraf. This is an open-access article distributed under the terms of the Creative Commons Attribution License (CC BY). The use, distribution or reproduction in other forums is permitted, provided the original author(s) or licensor are credited and that the original publication in this journal is cited, in accordance with accepted academic practice. No use, distribution or reproduction is permitted which does not comply with these terms. 